DOSSIÊ "História e literatura"

\title{
Sílvio Romero e Machado de Assis: leituras e dissensos do fim do Oitocentos
}

\author{
Alberto Luiz Schneider \\ Professor do Departamento de História - FFLCH - Universidade de São Paulo (USP) \\ alberto.ls@uol.com.br
}

Recebido em 30/06/2016. Aprovado em 02/09/2016.

Como citar este artigo: Schneider, A. L. "Sílvio Romero e Machado de Assis: leituras e dissensos do fim do Oitocentos". Intelligere, Revista de História Intelectual, São Paulo, v. 2, n 2 [3], p. 49-67. 2016. ISSN 2447-9020. Disponível em http://revistas.usp.br/revistaintelligere $>$. Acesso em dd/mm/aaaa.

Resumo: O objetivo deste artigo é explorar os dissensos no ambiente intelectual do fim do Século XIX, cujo debate girava em torno da literatura e da crítica literária por meio das obras de Machado de Assis e Sílvio Romero. O segundo, um dos principais críticos literários do país, atacou pesadamente a obra de Machado de Assis, já reconhecido como o maior romancista de sua época. O artigo almeja explorar as razões mais profundas da divergência, para além das disputas de espaço e prestígio no interior da República das Letras.

Palavras-chave: Brasil, História, Literatura, Machado de Assis, Sílvio Romero.

\section{Silvio Romero and Machado de Assis: readings and dissents at the end of the nineteenth century}

\begin{abstract}
The purpose of this article is to explore the dissent in the intellectual environment at the end of the 19th century, whose debate revolved around literature and literary criticism through the pieces of the literate Machado de Assis and the critic Sílvio Romero. Romero, a leading literary critic of the country, heavily attacked the work of Machado de Assis, who has been already recognized as the greatest novelist of that time. The article aims to explore the profound reasons of the divergence, besides the disputes of space and prestige within the Respublica litterarum.
\end{abstract}

Keywords: Brazil, History, Literature, Machado de Assis, Sílvio Romero. 
A experiência do tempo é marcada por uma historicidade particular - caracterizada por determinada maneira de ler o passado, experimentar o presente e vivenciar as expectativas de futuro. ${ }^{1}$ É possível captar e reconhecer traços dessa historicidade nos debates intelectuais de uma época e nos dissensos que os autores produzem. O que se quer, neste artigo, é vislumbrar aspectos do debate intelectual e político do Brasil de fins do Oitocentos, por meio das profundas divergências havidas entre Sílvio Romero ${ }^{2}$ - autor da História da literatura brasileira ${ }^{3}$ (1888) e o Machado de Assis ${ }^{4}$ da segunda fase - autor de Memórias póstumas de Brás Cubas (1881), O Alienista (1882), Quincas Borba (1891) e Dom Casmurro (1899), entre outras obras.

Os textos de Romero e Machado não serão abordados como meros reflexos de um tempo - e de um lugar -, nem como simples documento de uma época, mas também como reflexão sobre o Brasil de fins do século XIX. Reflexo e reflexão em permanente tensão. O ponto de partida deste texto está no livro que Sílvio Romero dedicou a Machado de Assis em 1897, o que implica em um duplo esforço: compreender o sentido mais geral da obra de Machado das décadas de 1880 e 1890 e a consequente crítica romeriana. Os textos mobilizados permitem vislumbrar a heterogeneidade, as fissuras e os dissensos na vida intelectual do que Antonio Candido chamou de "geração modernista de 1870", 5 um tempo de grandes transformações não apenas intelectuais e mentais, mas também políticas e sociais, como o esgotamento da Escravidão e do Império (18221889), bem como a chegada maciça de imigrantes ao Brasil.

A partir da década de 1870 outro país começou a despontar. O fim do tráfico negreiro (1850) e o lento declínio do consenso escravocrata, bem como a traumática experiência da Guerra do Paraguai afetaram a estabilidade imperial. Nas letras, a "geração de 1870" - na sua diversidade e multiplicidade -, assumiu discursos modernizadores. ${ }^{6} \mathrm{Na}$ definição do próprio Sílvio Romero, um "bando de ideias novas" povoou as cabeças intelectualizadas que então despontavam. Vivia-se um fascínio pelas últimas conquistas da civilização moderna, em que as ideias e as sensibilidades identificadas com a Segunda Revolução Industrial - em particular, a Ciência - emergiram como um instrumento explicativo da vida. ${ }^{7}$

Era um tempo de intensa crítica ao Romantismo. Tobias Barreto (1839-1889) e Sílvio Romero - egressos da Escola do Recife - assumiram uma eloquente defesa da Ciência, de onde deveriam partir as novas explicações da vida brasileira. Ferozes críticos do Indianismo, esses intelectuais avaliaram o que lhes pareciam ser as estruturas arcaicas do país. O engajamento em novos paradigmas mentais deveria servir como arma crítica a fim de subsidiar as necessárias intervenções políticas e sociais, no intuito de superar a Escravidão e o Império, bem como o indianismo romântico e o catolicismo, identificados como causa do "atraso", palavra que entrou

\footnotetext{
1 François Hartog, Regimes de historicidade: presentismo e experiências do tempo (Belo Horizonte: Autêntica, 2014), 133-191; Reinhard Koselleck, Passado Futuro: Contribuição à semântica dos tempos históricos (Rio de Janeiro: Contraponto / Editora da PUC-Rio, 2006), 191-327.

2 Sílvio Vasconcelos da Silveira Ramos Romero (1851-1914). Natural de Lagarto (Sergipe), graduou-se em 1873 na Faculdade de Direito do Recife, em Pernambuco. Foi advogado, professor, político, ensaísta, poeta, crítico literário, historiador, filósofo, cientista político, sociólogo e escritor, além de membro-fundador da Academia Brasileira de Letras (ABL). Radicado no Rio de Janeiro, onde morreu aos 63 anos de idade.

${ }^{3}$ Sílvio Romero, História da literatura brasileira, 2 vols. (Rio de Janeiro: Livraria Garnier, 1888); Nélson Romero, Prefácio a Sílvio Romero. História da literatura brasileira, 5 vols. (Rio de Janeiro: José Olympio, 1943); Sílvio Romero, História da literatura brasileira, Tomo 1 (Rio de Janeiro: José Olympio, 1953); Sílvio Romero, História da literatura brasileira, Tomos I e II, 2 vols. (Rio de Janeiro: Imago Editora, 2001).

${ }^{4}$ Joaquim Maria Machado de Assis (1839-1908). Nascido no Morro do Livramento, Rio de Janeiro, foi autodidata por excelência e tornou-se escritor, poeta, dramaturgo e contista renomado, embora tenha ganhado a vida como funcionário público e jornalista. Mulato de origem pobre, filho de mãe açoriana e pai descendente de escravos alforriados, casou-se em 1869 com Carolina Augusta Xavier de Novaes (1835-1904), natural do Porto, Portugal. Fundador da Academia Brasileira de Letras em 1897, e seu primeiro presidente, Machado de Assis morreu no Rio de Janeiro - cidade onde sempre viveu -, aos 69 anos.

${ }^{5}$ Sobre o engajamento de Sílvio Romero na geração de 1870, ver: Antonio Candido, O método crítico de Sílvio Romero (Rio de Janeiro: Ouro sobre Azul, 2006).

${ }^{6}$ Angela Alonso, Idéias em movimento - A Geração de 1870 na crise do Brasil-Império (Rio de Janeiro: Paz e Terra, 2002).

${ }^{7}$ Nicolau Sevcenko, Literatura como missão: tensões sociais e criação cultural na Primeira República (São Paulo: Editora Brasiliense, 1999), 25-41.
} 
no vocabulário político dos "modernizadores". Por ocasião da recepção de Euclides da Cunha (1866-1909) à Academia Brasileira de Letras (ABL), em 1906, Sílvio Romero rememorou a novidade representada pelo "bando de ideias novas", compreendido como uma aposta no futuro, o que exigia um rompimento com o velho e o atrasado: a Monarquia, a Escravidão e, no plano das letras, o Romantismo indianista.

Até 1868 o catolicismo reinante não tinha sofrido nestas plagas o mais leve abalo; a filosofia espiritualista, católica, eclética a mais insignificante oposição; a autoridade das instituições monárquicas o menor ataque sério por qualquer classe do povo; a instituição servil e os direitos tradicionais do aristocratismo prático dos grandes proprietários a mais indireta opugnação; o romantismo, com seus doces, enganosos e encantadores cismares, a mais apagada desavença. [...]

Um bando de ideias novas esvoaçou sobre nós de todos os pontos do horizonte. [...] Positivismo, evolucionismo, cientificismo na poesia e no romance, folk-lore, novos processos de crítica e história literária, transformação da instituição do direito e da política, tudo então se agitou e o brado de alarma partiu da escola do Recife. ${ }^{8}$

Não se trata aqui de aprofundar os meandros da "geração de 1870", mas de reconhecer a "desagregação" das estruturas políticas e mentais herdadas do Império, num momento de laicização, modernização e urbanização da vida brasileira em que as noções de centro e periferia, ou de atraso e modernidade, entraram na agenda nacional. A crise culminou no fim da Escravidão e da Monarquia. Os novos repertórios - republicanos, abolicionistas, imigrantistas, realistas e naturalistas, nacionalistas e cientificistas - geraram a necessidade de expurgar, seletivamente, determinadas ideias europeias, como a Monarquia e o Romantismo, em troca de outras, não menos europeias, como as Ciências, o Realismo e o Naturalismo, ou o Positivismo. Certamente diverso e mesmo conflitante, se pode afirmar, de acordo com Angela Alonso, que o movimento "intelectual" da geração de 1870 representa uma contestação à ordem imperial levada a cabo por grupos em maior ou menor grau marginalizados pelas instituições monárquicas. O movimento aproveitou-se do repertório europeu da segunda metade do Século XIX, apresentado como modernizador, a fim de encetar reformas, o que implicou na contestação da ordem imperial. ${ }^{9}$ Sílvio Romero e Machado de Assis tiveram de dar conta, cada qual a seu modo, desse clima de época que o país viveu.

A perspectiva ocidental e oitocentista de nação necessitou de ajustes e modificações. Muitos dos novos intelectuais, pós-românticos como Sílvio Romero, Tobias Barreto e Araripe Júnior (1848-1911), mesmo rompendo com o Romantismo literário, valorizaram as noções românticas de povo e nação. Os compromissos nacionalistas de Sílvio Romero, e mesmo os de intelectuais pouco mais jovens, como Euclides da Cunha, são eloquentes. Era preciso encontrar o "povo brasileiro" como os irmãos Grimm"10 haviam encontrado o "povo alemão" nas fábulas camponesas ${ }^{11}$ e como Jules Michelet (1798-1874) encontrara o "povo francês" na Revolução. ${ }^{12}$ A geração modernizante e cientificista da virada do Século XIX para o XX manteve o topos nacionalista, de matriz romântica, ajustando-o ao talhe objetivista, realista e naturalista em voga.

\footnotetext{
${ }^{8}$ Sílvio Romero, Discurso pronunciado aos 18 de dezembro de 1906, por ocasião da recepção do Dr. Euclydes da Cunha, In: Provocacões e debates: contribuições para o estudo do Brasil social (Porto: Lello \& Irmão Editores, 1910), 361-62.

${ }^{9}$ Angela Alonso, "Crítica e contestação: o movimento reformista da geração 1870", Revista Brasileira de Ciências Sociais, [vol.] 15, 44 (2000): (36-53).

${ }^{10}$ Irmãos Grimm: Jacob Ludwig Carl Grimm (1785-1863); Wilhelm Carl Grimm (1786-1859). Escritores, acadêmicos e linguistas foram estes dois irmãos nascidos em Hanau, Hesse (atual Alemanha). Eles foram responsáveis pela coleta e registro de inúmeras fábulas infantis alemãs - embora com origens sociais diversas e baseadas na tradição oral. $\mathrm{O}$ primeiro volume dos Contos de Grimm (Kinder-und Hausmärchen) foi publicado em 1812 e continha 86 estórias, como: Rapunzel, João e Maria, Cinderela, Chapeuzinho Vermelho e Os músicos de Bremen. Morreram aos 78 e 73 anos de idade, respectivamente.

${ }^{11}$ Sobre a busca do povo na cultura romântica do Século XIX, ver: Elias Thomé Saliba, As utopias românticas (São Paulo: Estação Liberdade, 2003), 39-54.

12 Jules Michelet, O Povo (São Paulo: Martins Fontes, 1988).
} 
Sílvio Romero, logo na abertura da História da literatura brasileira (1888), expressa inequivocamente sua visada nacionalista:

Se me faltou o talento, resta-me, em todo o caso, a face moral da empresa; a verdade e o patriotismo foram meus guias [...]. Independência literária, independência científica, reforço da independência política do Brasil, eis o sonho de minha vida. Sejam eles a tríplice empresa do futuro. Tenhamos confiança! ${ }^{13}$

A invenção das nações implicou uma profunda transformação política e cultural no mundo ocidental. A legitimidade do exercício do poder deixou de repousar no Príncipe, conforme a cultura política do Antigo Regime, e passou a estar no Povo, em nome do qual Luís XVI foi guilhotinado na França, em 1793. Não coincidentemente, o Século XIX é um tempo de monarquias declinantes e das repúblicas ascendentes. É o tempo, por excelência, do EstadoNação. A invenção das nacionalidades, lastreadas no conceito romântico de nação, fundado na ideia de um povo, uma língua e tradições étnico-culturais comuns, passou a demandar dos intelectuais uma identidade com esse povo. ${ }^{14}$ Nesse sentido, as palavras de Sílvio Romero, logo após a Proclamação da República, em 1889, são significativas:

O povo, e, quando dizemos o povo, referimo-nos àquela grande parte da nação que os aristocratas de todos os tempos chamaram desdenhosamente o terceiro e o quarto Estado, de onde, reparei bem, em sua maioria, saiu sempre o nosso glorioso exército; os homens de letras, e, quando dizemos os homens de letras, referimo-nos a todos aqueles que, tomando a si os encargos intelectuais da pátria, foram, no curso de quatro séculos, os fatos mais enérgicos e mais desinteressados de nosso progresso; plebe e pensadores, sempre estas duas forças caminharam aqui unidas! A história é testemunha. ${ }^{15}$

No caso brasileiro, a tarefa de reconhecer "o povo" como agente histórico (e político) tinha complicador de grandes proporções: "o povo" era, em larga medida, negro e mestiço. E foram justamente os não-brancos que estavam na alça de mira dos discursos deterministas e científicoracialistas dos autores europeus que os intelectuais brasileiros da geração de 1870 liam, entre eles Auguste Comte, ${ }^{16}$ Herbert Spencer, ${ }^{17}$ Ernst Haeckel ${ }^{18}$ e Ernest Renan, ${ }^{19}$ dentre outros. Esses discursos, contemporâneos ao imperialismo europeu, que culminou na Conferência de Berlim (1884-1885), chegaram ao Brasil justamente quando o escravismo se esgotara, o que, paradoxalmente, serviu para dar status científico ao racismo e embaraçar as aspirações de cidadania aos negros e mestiços, dois terços da população brasileira, segundo o Censo de 1872. A sedução de grande parte dos intelectuais brasileiros, inclusive Sílvio Romero, pelo universalismo cientificista e, frequentemente, racista levou-os a desconfiarem do destino de um país como o Brasil. ${ }^{20}$ Como o Brasil poderia alcançar o progresso e a civilização com a população que dispunha?

${ }^{13}$ Sílvio Romero, História da literatura brasileira, Tomo 1 (Rio de Janeiro: José Olympio, 1953), 48.

14 Anne-Marie Thiesse, A criação das identidades nacionais (Lisboa: Editora Temas e Debates, 2000), 27-69.

${ }^{15}$ Sílvio Romero, Novos estudos de literatura contemporânea (Rio de Janeiro: Garnier, 1898), 260.

16 Isidore-Auguste-Marie-François-Xavier Comte (1798-1857). Natural da cidade de Montpellier, o filósofo fundador do Positivismo foi autor de intensa obra sobre o tema, produzida entre os anos de 1830 a 1842. No Século XIX, alguns intelectuais brasileiros e o Exército nacional carregaram, em sua gênese, muito da ideologia positivista - ainda presente no dístico da bandeira do Brasil: Ordem e Progresso. Morreu em Paris, aos 59 anos de idade.

${ }^{17}$ Herbert Spencer (1820-1903). Filósofo inglês, adepto do liberalismo clássico e autor de O Indivíduo contra o Estado (The Man Versus the State, 1884). Morreu aos 83 anos, em Brighton, Inglaterra.

${ }^{18}$ Ernst Heinrich Philipp August Haeckel (1834-1919). Naturalista, biólogo, médico e filósofo -fundador do Monismo nascido em Potsdam, que colaborou com a divulgação da obra de Charles Darwin para o mundo, através de diversas palestras e publicação de trabalhos. Adepto do Positivismo cientificista, também soube exteriorizar através da arte do desenho os elementos e seres biológicos, uma imensa contribuição à Ciência Natural. Morreu aos 85 anos.

${ }^{19}$ Joseph-Ernest Renan (1823-1892). Historiador, filósofo, teólogo e escritor francês, de cuja vasta obra constam Averróis e o Averroísmo (1852), Vida de Jesus (1863), Marco Aurélio (1881) e a História do Povo de Israel (1887-1893, em 5 volumes). Morreu aos 69 anos, na cidade de Paris.

${ }^{20}$ Sobre o assunto, ver: Jeffrey D. Needell, Belle Époque tropical: sociedade e cultura de elite no Rio de Janeiro na virada do século (São Paulo: Companhia das Letras, 1993); Thomas E. Skidmore, Preto no branco: raça e nacionalidade no pensamento brasileiro (Rio de 
A pergunta mereceu respostas variadas, mas, de um modo ou de outro, foi quase impossível não discutir temas como a presença negra, a mestiçagem e a imigração europeia como alternativas. Machado de Assis, como se verá adiante, esteve entre os poucos homens de letras que descartaram a noção de "raça", bem como os de evolução e progresso - e ainda descartaria a retórica sobre o nacionalismo - como perspectivas organizadas de seu discurso literário. Diferentemente de Machado, Sílvio Romero foi um típico intelectual da geração de 1870, autor de uma "imagem nervosa do Brasil", como definiu Antonio Candido. ${ }^{21}$ Com História da literatura brasileira (1888), mais do que narrar a história da literatura, pretendia explicar o próprio Brasil. Romero, sem abdicar do nacionalismo de cunho romântico, queria "encontrar as leis gerais" e desvendar as que teriam presidido a formação do país, em chave-interpretativa de matriz naturalista, da qual foi um dos seus maiores artífices: "Neste terreno busca permanecer este livro, por mais lacunoso que ele possa vir a ser. Seu fito é encontrar as leis gerais que presidiram e continuam a determinar a formação do gênio, do espírito, do caráter do povo brasileiro". ${ }^{22}$

Sílvio Romero propunha compreender o Brasil através da literatura, alçada à condição de uma espécie de documento. A boa literatura deveria narrar o Brasil, suas gentes, sua história, ou seja, exprimir a sociedade, a cultura e, ao fim, a própria nação. As condições étnicas, mesológicas, sociais e históricas proporcionariam a chave pela qual a personalidade literária do autor se moldaria. As "criações do espírito", da qual a literatura seria expressão máxima, obedeceriam a determinações históricas e naturais. Daí, a necessidade de uma literatura que fizesse emergir "nosso caráter nacional":

Pretendo escrever um trabalho naturalista sobre a história da literatura brasileira. Munido do critério popular e étnico para explicar o nosso caráter nacional, não esquecerei o critério positivo e evolucionista da nova filosofia social, quando tratar de notar as relações do Brasil com a humanidade em geral. [...]; no primeiro livro indicam-se os elementos de uma história natural de nossas letras; estudam-se as condições de nosso determinismo literário, as aplicações da geologia e da biologia, as criações do espírito. ${ }^{23}$

O projeto intelectual romeriano buscou juntar uma perspectiva romântica, patente nas expressões "critério popular e étnico" e "caráter nacional", herdadas da cultura intelectual europeia da primeira metade do Século XIX, com as noções científicas e deterministas, próprias da segunda metade daquele século. Apesar do evidente fundo racialista, não deixou de registrar e eventualmente positivar a existência de uma imensa mestiçagem, afirmando estar nela o traço distintivo da singularidade nacional. O Brasil lhe pareceu mestiço de quatro séculos, embora sua população e sua cultura estivessem - e deveriam estar - em processo de embranquecimento e de ocidentalização:

O mestiço é o produto fisiológico, étnico e histórico do Brasil; é a forma nova de nossa diferenciação nacional. Nossa psicologia popular é um produto desse estado inicial. Não quero dizer que constituiremos uma nação de mulatos; pois a forma branca prevalece e prevalecerá; quero dizer apenas que o europeu aliou-se aqui a outras raças, e desta união saiu o genuíno brasileiro, aquele que não se confunde mais com o português e sobre o qual repousa nosso futuro. ${ }^{24}$

Janeiro: Paz e Terra, 1989); Thomas E. Skidmore, Preto no branco: raça e nacionalidade no pensamento brasileiro (São Paulo: Companhia das Letras, 2012); Roberto Ventura, Estilo tropical - História intelectual e polêmica literária no Brasil, 1870-1914 (São Paulo: Companhia das Letras, 1991); Alberto Luiz Schneider, Sílvio Romero, Hermeneuta do Brasil (São Paulo: Annablume, 2005); Rodrigo Turim, Tessituras do Tempo: discurso etnográfico e bistoricidade no Brasil Oitocentista (Rio de Janeiro: EDUERJ, 2014).

${ }^{21}$ Antonio Candido, "Fora do texto, dentro da vida". In: A educação pela noite e outros ensaios (São Paulo: Ática, 1987). 103; Antonio Candido, A educação pela noite e outros ensaios (Rio de Janeiro: Ouro sobre Azul, 2011).

22 Sílvio Romero, História da literatura brasileira, 74.

${ }^{23}$ Sílvio Romero, História da literatura brasileira, 58-59.

${ }^{24}$ Ibid., 132 


\section{Rusgas antigas}

Em 1897, Ś́lvio Romero escreveu um de seus livros mais polêmicos, em que ataca abertamente o já consagrado Bruxo do Cosme Velho. Trata-se de Machado de Assis: estudo comparativo da literatura brasileira, obra considerada um dos maiores equívocos da crítica literária nacional, ainda hoje; embora, sob o ponto de vista histórico, seja altamente reveladora dos dissensos da época. Apresentada na forma de peça de acusação, a obra de Romero foi definida por Roberto Ventura como um livro-tribunal. ${ }^{25}$

As desavenças começaram bem antes. Machado de Assis, em "A nova geração" - artigo publicado em 1879 na Revista Brasileira ${ }^{26}$-, atacou impiedosamente aos "moços", criticando o cientificismo dos aspirantes a homens de letras. Um dos "moços" em questão era Sílvio Romero, que havia publicado um livro de poesias chamado Cantos do fim do século (1869-1873), volume em que reuniu sua produção poética, escrita quando tinha entre 19 e 23 anos de idade. As palavras de Machado foram duras, então:

Os Cantos do fim do século podem ser também documentos de aplicação, mas não dão a conhecer um poeta; e para dizer tudo numa só palavra, o Sr. Romero não possui a forma poética. [...]. No livro do Sr. Romero achamos essa luta entre o pensamento que busca romper o cérebro, e a forma que não lhe acode ou só lhe acode reversa e obscura: o que dá a impressão de um estrangeiro que apenas balbucia a língua nacional. ${ }^{27}$

As considerações de Machado surtiram efeito. Romero jamais voltou a cometer versos, tampouco esqueceu a crítica. Em 1885 o historiador da Literatura escreveu artigo bastante positivo sobre Émile Zola (1840-1902), no qual aproveitou a ocasião para acusar o desafeto de ser uma espécie de manifestação tardia do Romantismo. ${ }^{28}$ No entanto, foi apenas em Machado de Assis: estudo comparativo da literatura brasileira (1897) que Sílvio Romero de fato acertou contas com o escritor. Em uma das passagens mais conhecidas e citadas pela crítica - exatamente por sua infelicidade -, Romero acusou a linguagem machadiana de "tartamudear"29 e não "ter grande originalidade". Haveria uma "gagueira" na escrita de Machado de Assis, que bem representaria o espírito tíbio e alheio às lutas sociais:

O estilo de Machado de Assis, sem ter grande originalidade, sem ser notado por um forte cunho pessoal, é a fotografia exata do seu espírito, de sua índole psicológica indecisa. [...]. Vê-se que ele apalpa e tropeça, que sofre de uma perturbação qualquer nos órgãos da palavra. Sente-se o esforço, a luta. [...]. De fato, Machado de Assis repisa, repete, torce, retorce, tanto suas ideias e as palavras que as vestem, que deixa-nos a impressão dum perpétuo tartamudear. ${ }^{30}$

${ }^{25}$ Roberto Ventura, Estilo Tropical: História cultural e polêmicas literárias no Brasil, 1870-1914 (São Paulo: Companhia das Letras, 1991), 95-107.

${ }^{26}$ Revista Brasileira. Em julho de 1855, surgiu no Rio de Janeiro uma publicação denominada Revista Brazileira, Jornal de Literatura, Teatros e Indústria, fundada e dirigida pelo Dr. Francisco de Paula Meneses. Passados alguns anos, e então mais conhecida por Revista Brazileira - em sua Fase III, a chamada "fase José Veríssimo" -, contou com circulação de janeiro de 1895 a setembro de 1899 , completando vinte volumes em cinco anos.

http://www.academia.org.br/publicacoes/revista-brasileira [acessado em 11 de abril, 2016].

${ }^{27}$ Machado de Assis, "A nova geração". In: Obra Completa de Machado de Assis, vol. III (Rio de Janeiro: Nova Aguilar, 1994), 815.

28 Sobre o assunto, ver: Sílvio Romero, "Sobre Émile Zola”. In: Sílvio Romero: teoria, crítica e bistória literária, org. Antonio Candido (Rio de Janeiro / São Paulo: Livros Técnicos e Científicos / EDUSP, 1978).

${ }^{29}$ A ironia de Sílvio Romero nesta crítica é maldosa, pois Machado de Assis era possuído por uma gagueira que muito o constrangia socialmente, além do fato de ser mulato, de jaez introvertido e epiléptico. Assim, o "repisa, repete, torce e retorce" devem ter causado reconhecido sofrimento ao escritor fluminense.

${ }^{30}$ Sílvio Romero, Machado de Assis: estudo comparativo de literatura brasileira (Campinas: Editora da UNICAMP, 1992, reimp.), 122. 
Certamente há no texto de Sílvio Romero o desejo de devolver a acusação que Machado de Assis havia the dirigido no passado. No entanto, embora as disputas eruditas entre os grupos fossem relevantes no interior de uma comunidade intelectual, é uma visão redutora limitar as diferenças aos ressentimentos e disputas por visibilidade e prestígio. O desacordo foi muito mais profundo e passava por seus engajamentos políticos, estéticos e conceituais. A obra de Machado não coube nos ideais romerianos e foi-lhe um problema de grandes proporções. Romero possuía a consciência de que a obra de Machado de Assis era uma literatura de grande densidade estética e reconheceu-lhe o mérito. Referindo-se ao Capítulo VII de Memórias póstumas de Brás Cubas - "O delírio", após transcrevê-lo integralmente, comentou o crítico:

Belo, realmente muito belo, como linguagem e estilo. É sem dúvida uma das páginas mais intensas da língua portuguesa. Nem Vieira, nem Herculano, nem Camilo, nem Eça, nem Rui, possuem muitas que a possam ultrapassar. Por amor dela, era caso de estar quase arrependido de tudo quanto, mais ou menos desfavorável, tenho dito em todo o correr deste livro a respeito do romancista fluminense. ${ }^{31}$

Um dos objetivos mais evidentes da acusação romeriana foi questionar a posição canônica que Machado de Assis já havia conquistado no ambiente intelectual e literário da época. Porém, mais do que qualquer outra questão, Sílvio Romero buscou criticar a alegada falta de compromisso nacional por parte de Machado. Em certo sentido, a crítica representou menos uma discussão literária propriamente dita e mais uma disputa em torno de ideias ou preferências intelectuais, estéticas e políticas. Representou, inclusive, uma disputa regional, pois Romero questionava o "afrancesamento" dos intelectuais fluminenses reunidos em torno do Bruxo do Cosme Velho, bem como a defesa de homens de letras da chamada Escola do Recife, particularmente Tobias Barreto.

Machado de Assis, já consagrado, não se defendeu das acusações de Romero, mas Lafayette Rodrigues Pereira (1834-1917) - sob o pseudônimo de Labieno - tomou as dores de Machado e publicou, em 1899, o Vindiciae, o Sr. Sílvio Romero crítico e filósofo, aonde o acusa de "o sacrificador bárbaro que veio lá das regiões cimeiras"; de sujeito que "fala uma língua dura, de umas gramáticas impossíveis, contaminadas da ferrugem de aldeia". ${ }^{32}$ E, conclui Lafayette, não sem alguma razão:

Machado de Assis é o pretexto. O objeto do livro é Tobias, é a glorificação do Teuto sergipano. Bem sabia o Senhor Romero que se houvesse dado ao livro a sua verdadeira denominação - Tobias Barreto - não teria leitores. ${ }^{33}$

Ao atacar Machado de Assis, Sílvio Romero intentava, entre outras coisas, também atacar a posição central ocupada pelo Rio de Janeiro no ambiente intelectual brasileiro da época, e que, segundo dizia, emularia o espírito oligárquico da elite política brasileira, no qual Machado exerceria "uma espécie de política dinástica na literatura". 34 Entre outros alvos, Romero buscava golpear a "capelinha fluminense" liderada por Machado de Assis, Joaquim Nabuco (1849-1910) e José Veríssimo (1857-1916), grande adversário do crítico sergipano.

Brito Broca (1903-1961), antigo estudioso do ambiente literário brasileiro, então confirmava: "uma atitude objetiva e imparcial nos leva a reconhecer no autor de Dom Casmurro a

\footnotetext{
${ }^{31}$ Sílvio Romero, Machado de Assis: estudo comparativo de literatura brasileira, 140.

32 Trecho da defesa a Machado de Assis por Lafayette Rodrigues Pereira, em 1899.

http://www.academia.org.br/academicos/lafayette-rodrigues-pereira/textos-escolhidos [acessado em 11 de abril, 2016]

${ }^{3}$ Ibid.

${ }^{34}$ Sílvio Romero, Machado de Assis: estudo comparativo de literatura brasileira, 117.
} 
mais viva tendência para as "capelinhas' entre nós". ${ }^{35}$ A rigor, a crítica a Machado passou por um conjunto de aspectos - que vão desde a disputa de espaço e prestígio num ambiente culturalmente restrito, até diferenças políticas e estéticas de grandes proporções, passando por velhos ressentimentos. Antes de prosseguir na exposição do visceral desconforto romeriano ante Machado de Assis, é preciso compreender as recusas do Bruxo do Cosme Velho.

\section{As recusas de Machado de Assis}

No Machado de Assis da segunda fase - de textos como Memórias póstumas de Brás Cubas (1881), O Alienista (1882), Quincas Borba (1891) ou Dom Casmurro (1899) - se pode observar um romancista já claramente pós-romântico, pois profundamente diferente de José de Alencar, até àquele momento aclamado pelos leitores e pela crítica como o grande escritor brasileiro. Machado, ao fugir do Nacionalismo por um lado, e do Naturalismo e do Realismo, por outro; ao fazer pouco caso dos progressos de seu tempo, como a Ciência; ao recusar o engajamento em causas públicas, como a Abolição e a República, pode ser lido como uma espécie de anti-Romero. Desse modo, o escritor pode ser considerado o avesso do crítico em muitos sentidos: no estilo, nas leituras, nas posições políticas, nas rodas de convivência, na origem social e regional. Eram diferentes, sobretudo, na compreensão da literatura e no lugar que o Brasil ocuparia no texto literário.

Antonio Candido - em "Esquema de Machado de Assis" - nota que o escritor fluminense, na feição que assumiu na década de 1880, teve na boa linguagem, na ironia fina, na urbanidade amena e no tom refinado sua marca inconfundível. A "discrição" - permeados de subentendidos, alusões e eufemismos - emprestava aos seus contos e romances a capacidade de não chocar "as exigências da moral familiar", ao contrário do Naturalismo, com "descrição minuciosa da vida fisiológica”. O humor e o pessimismo elegante, as referências a filósofos do Século XVIII e a Bíblia faziam da "leitura uma experiência agradável”, o que acabava por lisonjear "o público mediano, inclusive os críticos, dando-lhes o sentimento de que eram inteligentes a preço módico". ${ }^{36}$ No entanto, demonstra Candido, atrás do bom moço, havia o "desmascaramento" dos homens e da própria sociedade, ainda que evitasse um tom que poderíamos chamar de "sociologizante":

Sob o rapaz alegre e mais tarde burguês comedido que procurava ajustar-se às manifestações exteriores, que passou convencionalmente pela vida, respeitando para ser respeitado, funcionava um escritor poderoso e atormentado, que recobria os seus livros com a cutícula do respeito humano e das boas maneiras para poder, debaixo dela, desmascarar, investigar, experimentar, descobrir o mundo da alma, rir da sociedade, expor algumas das componentes mais esquisitas da personalidade. $\mathrm{Na}$ razão inversa de sua prosa elegante e discreta, do seu tom humorístico e ao mesmo tempo acadêmico, avultam para o leitor atento as mais desmedidas surpresas. ${ }^{37}$

A observação de Candido sobre os leitores é importante. De fato, o estilo de Machado de Assis permitiu camadas de leitura facilmente tragáveis para o gosto médio e conservador, inclusive estilisticamente. É preciso observar a historicidade da recepção de Machado. Quando da publicação de Memórias póstumas, em 1881 (saiu antes, em 1880, em fragmentos, na Revista Brasileira), a acolhida dos leitores foi relativamente modesta. ${ }^{38}$ Bem mais calorosa - nota Haroldo Cevarolo, ${ }^{39}$ citando Helen Caldwell - foi a recepção de O Mulato (1881), de Aluísio Azevedo

\footnotetext{
${ }^{35}$ Brito Broca, “As ‘capelinhas' literárias”. In: Teatro das letras (Campinas: Editora da UNICAMP, 1993), 15.

36 Antonio Candido, "Esquema de Machado de Assis". In: Vários Escritos (São Paulo: Duas Cidades, 1995), 22; Antonio Candido, Vários Escritos (Rio de Janeiro: Ouro sobre Azul, 2011).

37 Antonio Candido, Vários Escritos, 23.

${ }^{38}$ Hélio Seixas Guimarães, Os leitores de Machado de Assis (São Paulo: Nankin / EDUSP, 2012), 192.

${ }^{39}$ Haroldo Ceravolo Sereza, "O Brasil na Internacional Naturalista: adequação da estética, do método e da temática naturalistas no romance brasileiro do Século 19” (Tese de doutorado, Universidade de São Paulo - FFLCH-USP, 2012), 63.
} 
(1857-1913). Em outras palavras, o Machadinho - como era chamado quando jovem - estava se tornando Machado de Assis, operação que demandou, além do próprio texto literário, o investimento da crítica e dos leitores. Mas é claro que a força do texto machadiano é incontornável. É ainda Candido quem observa que sua técnica narrativa consistia

[...] em sugerir as coisas mais tremendas da maneira mais cândida (como os ironistas do Século XVIII); ou em estabelecer um contraste entre a normalidade social dos fatos e a sua anormalidade essencial; ou em sugerir, sob a aparência do contrário, que o ato excepcional é normal, e o anormal seria o ato corriqueiro. Aí está a modernidade, apesar do seu arcaísmo de superfície. ${ }^{40}$

São conhecidas as páginas de $O$ Alienista (1882), em que Machado de Assis ironiza o médico-cientista, o Dr. Bacamarte, que acaba internado no próprio asilo - Casa Verde - em que dirigia suas pesquisas e experimentos e onde internava aos demais moradores da cidade de Itaguaí. É conhecido o "Humanitismo", que "retifica o espírito humano, suprime a dor, assegura a felicidade, enche de imensa glória nosso país". ${ }^{41}$ Eis a filosofia elaborada pelo personagem Joaquim Borba dos Santos, em Quincas Borba (1891). Trata-se de evidente sátira em relação ao Positivismo, ao Naturalismo e ao Cientificismo evolucionista de seu tempo. A teoria do "ao vencedor, as batatas" pode ser lida como uma paródia das leis científico-evolutivas, da "luta pela vida com sobrevivência do mais apto". ${ }^{42}$ Lembremos que Brás Cubas, em Memórias póstumas (1881), busca notoriedade por meio de um emplastro, uma invenção científica.

Não há dúvida que livros como O Mulato (1881) e O Cortiço (1890), ambos de Aluísio Azevedo - cuja proximidade com o Republicanismo, o Positivismo e o Abolicionismo são evidentes - se encaixaram melhor no horizonte de expectativa literária de Sílvio Romero do que Memórias póstumas de Brás Cubas (1881) e Dom Casmurro (1899). Esses romances, narrados em primeira pessoa e pautados pela (auto) reflexão, pelo apuro da linguagem e pelo caráter especulativo - que narra antes pensamentos e sentimentos do que acontecimentos e descrições, quase sempre em tom subjetivo e interno, contraditam vivamente com a expectativa literária de Romero, que cobrava dos escritores engajamento nas lutas do mundo e do tempo, fé na ciência, vontade (liberal) de progresso, empenho na construção da nacionalidade (não apenas literária). No Machado maduro, além das questões universais - como o ciúme, o interesse, a dissimulação - há também, como sugere Candido -, questões relativas à "estrutura social” próprias da sociedade em que o escritor fluminense viveu:

Pela sua obra toda há um senso profundo, nada documentário, do status, do duelo dos salões, do movimento das camadas, da potência do dinheiro. O ganho, o lucro, o prestígio, a soberania do interesse são molas dos seus personagens, aparecendo em Memórias póstumas de Brás Cubas, avultando em Esaú e Jacó, predominando em Quincas Borba, sempre transformando em modos de ser e fazer. E os mais desagradáveis, os mais terríveis dos seus personagens, são homens de corte burguês impecável, perfeitamente entrosados nos mores da sua classe. ${ }^{43}$

A obra de Machado de Assis é marcada por recusas. Uma delas foi a de aderir às escolas naturalistas e realistas, tal como haviam feito escritores europeus como Émile Zola ou Eça de Queiroz (1845-1900), de grande repercussão no Brasil do último quartel do Século XIX. Recusa extensiva à própria ciência da época, da qual Machado guardou distância ou ironia. Recusa que já estava configurada na famosa crítica de Machado de Assis a Eça de Queiroz, por "atirar-se ao

\footnotetext{
${ }^{40}$ Antonio Candido, Vários Escritos, 29.

${ }^{41}$ Machado de Assis, "Memórias póstumas de Brás Cubas", cap. 91, In: Obra Completa de Machado de Assis, vol. I (Rio de Janeiro: Nova Aguilar, 1994).

${ }^{42}$ Antonio Candido, Vários Escritos, 34.

${ }^{43}$ Ibid., 38.
} 
inventário", sem esquecer nem ocultar nada, na condição de discípulo realista-naturalista que acredita que "só chegará à perfeição no dia em que nos disser o número exato dos fios de que se compõe um lenço de cambraia ou um esfregão de cozinha". ${ }^{44}$ Machado, apesar de não ocultar a dissidência, não condena escolas literárias e seus autores de modo absoluto, mas defende seu próprio projeto literário, marcado pela recusa estilística e temática tanto do Naturalismo como do Realismo. ${ }^{45}$

O Machado de Assis da segunda fase também recusou uma sensibilidade de cunho nacionalista, atitude política e intelectual incomum em fins do Século XIX, tempo de intenso nacionalismo em todo o Ocidente. Mas não pôde fugir de tão candente assunto. Em 1873, o autor escreveu um célebre artigo intitulado "Instinto da nacionalidade", em que se pode ver um Machado respeitoso em relação à tradição herdada do Romantismo, em que ainda se vê o uso da expressão como a "cor local". O escritor enxergou linhas de continuidade na jovem tradição literária luso-brasileira - desde Santa Rita Durão (1722-1784), no Século XVIII, até o indianismo de Gonçalves Dias (1823-1864) -, cujas linhas deveriam continuar na "geração que ainda agora madruga", a despeito das diferenças. Machado de Assis, diferentemente de Sílvio Romero, não leu a tradição com o gosto moderno pelo futuro e retórica do progresso, reconhecendo no Romantismo brasileiro - empenhado em narrar a índios alegóricos e a natureza tropical - o "instinto da nacionalidade":

Quem examina a atual literatura brasileira reconhece-lhe logo, como primeiro traço, certo instinto de nacionalidade. Poesia, romance, todas as formas literárias do pensamento buscam vestir-se com as cores do país, e não há como negar que semelhante preocupação é sintoma de vitalidade e abono do futuro. [...]. Interrogando a vida brasileira e a natureza americana irão dando fisionomia própria ao pensamento nacional. ${ }^{46}$

A percepção machadiana não se pautou pela negação absoluta da tradição, como fizera Romero, que identificava no Romantismo literário brasileiro "a falta de crítica, a paixão da palavrosidade com prejuízo das ideias e um otimismo extravagante sobre os nossos homens e as nossas coisas". ${ }^{47}$ Machado de Assis não aceitou restringir a literatura às obras que versassem sobre assunto "local" ou "nacional", pois antes interessava a condição propriamente literária do fenômeno, independente de outros compromissos. Para ele, o que se deveria "exigir do escritor antes de tudo, é certo sentimento íntimo, que o torne homem do seu tempo e do seu país, ainda quando trate de assuntos remotos no tempo e no espaço". ${ }^{48}$ Sem destruir a tradição, valendo-se da estratégia de afirmar, legitimar e, posteriormente, negar e atenuar, o romancista acabou por romper a linearidade do paradigma em torno do nacional.

O crítico português Abel Barros Baptista ao comentar o Instinto da Nacionalidade, influente ensaio de 1873, e a realização de Memórias póstumas de Brás Cubas, o importante romance de 1881, nota a recusa machadiana em aceitar a prescrição nacionalista herdada da geração anterior sem, contudo, negar a validade da operação nacional levada a cabo pelos fundadores da Literatura Brasileira. Machado teria procurado "delimitar um estatuto para a sua assinatura resistindo à lei nacional”, afirma Barros Baptista. Para ele, "reflexão machadiana sobre a questão da nacionalidade

\footnotetext{
${ }^{44}$ Machado de Assis, “O primo Basílio". In: Obra Completa de Machado de Assis, vol. III (Rio de Janeiro: Nova Aguilar, 1994), 913.

45 Por importante que seja, não nos interessa aqui aprofundar as diferenças e matizes entre o Naturalismo e o Realismo. A discussão é extensa, mas um excelente ponto de partida está em "Machado de Assis e o problema do 'realismonaturalismo"'. Cf. Haroldo Ceravolo Sereza, “O Brasil na Internacional Naturalista: adequação da estética, do método e da temática naturalistas no romance brasileiro do Século 19" (Tese de doutorado, Universidade de São Paulo - FFLCHUSP, 2012). 60-96. Sobre Eça de Queiroz e o Brasil, ver: José Leonardo Nascimento, O "Primo Basílio" na imprensa brasileira do Século 19 - Estética e História (São Paulo: Editora da UNESP, 2008).

${ }^{46}$ Machado de Assis, Obra Completa de Machado de Assis, 801.

${ }^{47}$ Sílvio Romero, A literatura e a crítica moderna (Rio de Janeiro: Imprensa Industrial de João Ferreira Dias, 1880). 186.

${ }^{48}$ Machado de Assis, Obra Completa de Machado de Assis, 804.
} 
literária desarticula a retórica solidária do projeto nacional legado pelo Romantismo, quebrando o laço entre a realidade brasileira entendida como realidade fundadora e a literatura". ${ }^{49}$ Em outras palavras, Machado não teria se engajado na tarefa de construir o Brasil, mas sim de construir uma literatura que, por mais brasileira que fosse, seria antes de tudo literatura. A perspectiva de Machado de Assis não exige da Literatura Brasileira um compromisso final com a construção do próprio país. O texto literário deveria servir-se de liberdade criadora, e não ser determinado por fatores extraliterários: "tudo é matéria de poesia, uma vez que traga as condições do belo ou os elementos de que ele se compõe". ${ }^{50}$

Machado de Assis, ao propor o "sentimento íntimo" como fundamento do "instinto da nacionalidade", conseguiu desvincular-se da tradição romântica, sem com isso aderir às escolas e teses hegemônicas de fins do Século XIX, o que possibilitou um prudente afastamento dos determinismos étnicos e geográficos, tentação que poucos homens de letras de seu tempo souberam evitar. A noção machadiana de "sentimento íntimo" foi suficientemente aberta para não negar as condições nacionais e suas possibilidades literárias, mas "recusar" o exclusivismo nacionalista e determinista. Trata-se de criativa elisão do nacionalismo mais empobrecido. Em Machado predomina uma visada interior, subjetiva e reflexiva. Ao evitar tanto a tradição romântica, quanto às novidades conceituais recém-desembarcadas da Europa da segunda metade do Século XIX, o escritor soube perceber a dimensão teleológica do horizonte discursivo do modernismo cientificista da "nova geração", que lhe pareceu "o inverso da tradição bíblica: é o paraíso no fim". ${ }^{51}$ Tratava-se, pois, de uma crítica à visão redentora do progresso, bem como uma recusa a automática adesão (ou ruptura) frente ao passado europeu, inclusive recolhendo da tradição europeia o que ela própria desvalorizava no Século XIX; Cervantes, por exemplo. Como Jorge Luís Borges (1899-1986) fizera depois, Machado teria escolhido seus precursores. Ao recusar a dimensão totalizadora do projeto nacional e da retórica do progresso, estava por recusar as tradições hegemônicas do Século XIX. Nada mais anti romeriano.

\section{O escritor como crítico do crítico}

Quando Sílvio Romero elogiava o estilo do escritor fluminense - "parece que honro Machado de Assis, quero dizer, rendo-lhe a homenagem de que é merecedor, como príncipe do estilo entre nós" 52 - tratava-se, na verdade, de uma crítica, pois servia para representar um Machado alheio à luta política e social. É preciso lembrar que Romero simplesmente não podia identificar em Machado a crítica social, patente na exibição das hierarquias e na dependência dos pobres livres e agregados em relação às classes proprietárias, inclusive a forma máxima de dependência e hierarquia, a Escravidão. Essa tradição crítica - aberta por Roberto Schwarz, John Gledson e Sidney Chalhoub, entre outros - evidentemente não estava, nem podia estar, no horizonte interpretativo romeriano. Não podemos esquecer que a crítica, além de histórica, é permeada por tradição discursiva que educa o olhar e a recepção. Romero recepcionou a literatura de Machado em linha com seu compromisso com a nacionalidade e o progresso: "como todas as literaturas do mundo, deve ser a expressão positiva do estado emocional das ideias e dos sentimentos de um povo". Mas, quem era o "povo brasileiro"? "Ora, nosso povo não é o índio, não é o negro, não é o português; é antes a soma de todas estas parcelas atiradas ao cadinho do Novo Mundo", já o dissera na História da literatura brasileira. ${ }^{53}$

Machado de Assis seria "um brasileiro em regra, um nítido exemplar dessa sub-raça americana, que constitui o tipo diferencial da nossa etnografia [...]. Ele é um dos nossos, um

\footnotetext{
49 Abel Barros Baptista, A formação do nome: duas interrogações sobre Machado de Assis (Campinas: Editora da UNICAMP, 2003). 42.

${ }^{50}$ Machado de Assis, Obra Completa de Machado de Assis, 806.

${ }^{51}$ Ibid., 811.

52 Sílvio Romero, Machado de Assis: estudo comparativo de literatura brasileira, 117; 129.

${ }^{53}$ Sílvio Romero, História da literatura brasileira, 412.
} 
genuíno representante da sub-raça brasileira cruzada". ${ }^{54}$ Por parecer, aos olhos de Romero, um "nítido exemplar" de nossa "sub-raça", caberia a Machado um investimento nas questões brasileiras que o escritor fluminense teria se recusado. Como um mulato nascido pobre no Morro do Livramento, no Rio de Janeiro, ${ }^{55}$ que veio a tornar-se grande escritor, nem condenou nem defendeu a mestiçagem, e também não escreveu páginas vibrantes sobre os grandes dramas do país? Romero pretendeu ler a obra de Machado "à luz de seu meio social, da influência de sua educação, de sua psicologia, de sua hereditariedade fisiológica e étnica, mostrando a formação, a orientação normal de seu talento". ${ }^{56}$ A leitura do crítico, nota Hélio Seixas Guimarães, estava interessada em ver no texto literário o "fator de diferenciação e progresso", capaz de "refletir a sociedade a que pertence". 57

Ao não assumir a sua condição de "meridional e mestiço", o escritor fluminense soava-lhe afetado, constituindo-se em uma espécie de impostura, artificial, alheio ao meio (brasileiro). Sem muita sutileza, como lhe era característico, Sílvio Romero assentava no colo de Machado a imagem do mulato pernóstico, afrancesado, com afetação de erudição e finura, incapaz de aceitar o seu lugar na sociedade. Trata-se de uma imagem recorrente no Século XIX, e mesmo depois. A propósito, Gilberto Freyre (1900-1987), em livro de 1955, em que confronta as obras de José de Alencar (1829-1877) e de Machado de Assis retoma essa percepção:

Um Machado a fingir-se o tempo inteiro de branco fino: o tempo inteiro a bater janelas e a fechar portas contra toda espécie de paisagem mais cruamente brasileira, fluminense ou carioca em suas cores vivas; contra todo o arvoredo mais indiscretamente tropical que lhe recordasse sua meninice de rua e de morro, sua condição de filho de gente de cor, filho de família plebeia, de descendente de escravo negro. Nada de paisagem, nada de cor, nada de árvore, nada de sol. ${ }^{58}$

A observação de Freyre, hostil a Machado, é digna de Romero, para quem Machado sofria a "moléstia da cor", despeitado em relação aos "que gozam da superioridade da branquidade". Apesar do tom francamente racista, Sílvio Romero considerou a presença africana muito mais importante e influente na formação do Brasil do que a dos indígenas. Aludiu positivamente a mestiçagem entre brancos e negros, cujo "influxo penetrou em nossa vida íntima", definindo os africanos como "robustos, ágeis". Além disso, o negro seria "domável", diferente dos indígenas, "improdutivos". Ao referir-se à Escravidão, Romero não empregou o verbo escravizar. Preferiu outro modo de dizer: o colono português "recorreu a um auxiliar poderoso, o negro da África". A citação é longa, mas proveitosa:

A raça africana tem tido no Brasil uma influência enorme, somente inferior à da raça europeia; seu influxo penetrou em nossa vida íntima e por ele moldou-se em grande parte nossa vida psicológica popular. [...] O português julgou-se fraco para repelir o selvagem e para o amanho das terras, e recorreu a um auxiliar poderoso (grifo meu), o negro da África. Ao passo que o índio tornava-se improdutivo, fugia,

54 Sílvio Romero, "Século XIX (Fase Romântica), 1830-1880, vol. III - Prosadores: ainda dramaturgos e romancistas". In: Compêndio de História da Literatura Brasileira - Obras Completas de Sílvio Romero (Rio de Janeiro, Aracaju: Imago Editora / Editora da UFS, 2001), 281.

${ }^{55}$ Joaquim Maria Machado de Assis nasceu na região central - zona portuária do Rio. O Morro do Livramento localiza-se entre os Morros da Conceição e da Providência. A casa em que nasceu em 1839, aos 21 de junho - e que ainda hoje resiste, quase em ruínas, passados 177 anos do nascimento do escritor - ficava em terras do engenheiro-militar e senador do Império do Brasil, Bento Barroso Pereira (1785-1837). Sua viúva, Dona Maria José de Mendonça Barrozo Pereira, foi madrinha de Machado. Para maiores informações sobre o nascimento e os primeiros anos do escritor, ver: Lúcia Miguel Pereira, Machado de Assis: estudo crítico e biográfico (Belo Horizonte, São Paulo: Editora Itatiaia / EDUSP, 1988), 28-44.

${ }^{56}$ Sílvio Romero, Machado de Assis: estudo comparativo de literatura brasileira, 79.

${ }^{57}$ Hélio Seixas Guimarães, "Romero, Araripe, Veríssimo e a recepção crítica do romance machadiano", Revista Estudos Avançados [vol.] 18, 51 (2004) (269-298). Sobre a recepção mais ampla de Machado, ver: Hélio Seixas Guimarães, Os leitores de Machado de Assis (São Paulo: Nankin / EDUSP, 2012).

58 Gilberto Freyre, Reinterpretando José de Alencar (Rio de Janeiro: Ministério da Educação e Cultura - Serviço de Documentação, 1955), 9. 
esfacelava-se e morria, durante mais de três séculos foram chegando levas e levas de africanos robustos, ágeis e domáveis, e foram fundando as fazendas e engenhos, as vilas e as cidades e permanecendo no seio das famílias coloniais. ${ }^{59}$

Sílvio Romero não reduziu a mestiçagem a um fenômeno meramente biológico, mas o estendeu à cultura popular. Abordou o "fenômeno da fusão e mestiçamento das cantigas populares, romances, xácaras, orações, parlendas" ${ }^{60}$ e das alterações linguísticas pela qual a língua portuguesa passara no Brasil: "O luso-brasileiro contém inúmeras palavras tupis [...]. Encerra um grandíssimo número de termos de origem africana, como: batuque, cafuné, senzala, cachimbo, maracatu, quiabo, munganga, xará, calunga, mocambo etc.". ${ }^{61}$ Se o leitor associou o argumento romeriano à obra de Gilberto Freyre, convém saber que em Casa-Grande \& Senzala, Sílvio Romero foi citado em notas de rodapé e no corpo do texto por diversas vezes. O próprio Freyre, em artigo de jornal de 1951 - por ocasião do centenário do nascimento de Sílvio Romero -, elogiou voluptuosamente a busca romeriana por uma "brasilidade" mestiça, ao afirmar que "História da literatura brasileira é um desses livros que protegem um povo contra a agressão e o desânimo, como se fossem fortalezas, e, ao mesmo tempo, igrejas". ${ }^{62}$

Seria fácil, e sobretudo equivocado, reduzir a má vontade de Romero em relação a Machado em função da condição de mulato do autor de Dom Casmurro. Mulato também o era seu mestre do Recife, Tobias Barreto, a quem Romero destinava eloquentes elogios. Para Candido, Romero acabou "não compreendendo nem querendo compreender" a obra de Machado, pois escaparia à "orientação esquemática e maciçamente naturalista do seu espírito". ${ }^{63}$ Diferentemente do que sugere o professor Antonio Candido, é possível argumentar que Romero assumiu a onerosa missão de enfrentar Machado de Assis justamente por que compreendeu sua obra. O crítico identificou no discurso literário machadiano um poderoso adversário frente aos ideais nacionalistas, cientificistas e progressistas (no sentido de republicano militante, partidário do progresso, da imigração estrangeira e da ciência etc.). A obra de Machado havia se convertido num verdadeiro problema para o autor da História da literatura brasileira, pois sequer podia ignorá-la, devido ao prestígio que Machado de Assis alcançara; nem podia aceitá-la, sob pena de comprometer todo o seu edifício intelectual e político. Afinal, não eram nem as questões formais e estilísticas, nem a especificidade do escritor que o interessavam, mas, sim, a capacidade do literato em expressar, sociologicamente, a vida do país e da história, do "povo" e da "raça", tal como Romero afirmara em 1888:

O meio de evitar estes desacertos díssonos e comprometedores é, repetimos, generalizar: ver o povo, onde de ordinário só se costuma enxergar o indivíduo; tomar a evolução das letras e das artes como uma coisa impessoal, de superior às cotteries de momento, como espécie expoente da vida nacional, uma função da capacidade espiritual da raça. Olhando desta altura da região das ciências, letras e artes, não deixa ela ver os rancorosos conflitos do egoísmo, a pequenez dos temperamentos, o lado passageiro das paixões, para só descortinar aos olhos do observador os grandes, os nobres esforços da alma do povo para a luz, para a glória, para o belo, para os deslumbramentos do porvir. ${ }^{64}$

A partir desse horizonte interpretativo, enxergou no bumour machadiano a imitação afetada de autores ingleses, em desacordo com o "caráter" do povo brasileiro, supostamente mais afeito à

\footnotetext{
${ }^{59}$ Sílvio Romero, História da literatura brasileira, 147.

${ }^{60}$ Sílvio Romero, "Novas contribuições para o estudo do folclore brasileiro". In: História da literatura brasileira, Tomo 1 (Rio de Janeiro: José Olympio, 1953), 185. (Obs. O texto, de 1910, foi incluído por Nélson Romero na História da literatura brasileira - a partir da $3^{\mathrm{a}}$ edição - e publicada pela José Olympio).

${ }^{61}$ Sílvio Romero, História da literatura brasileira, 143.

${ }^{62}$ Gilberto Freyre, “O gigante Sílvio Romero”, Correio Popular (Campinas), 22 de abril de 1951.

${ }^{63}$ Antonio Candido, Vários Escritos, 38.

${ }^{64}$ Sílvio Romero, História da literatura brasileira, 43.
} 
"sátira” que à ironia: "o temperamento, a psicologia do notável brasileiro não são os mais próprios para produzir o bumour, essa particularíssima feição da índole de certos povos". ${ }^{65}$ Tampouco o humor de Machado seria "compatível com as nossas raças ibero-áfrico-americanas". ${ }^{66}$

Sílvio Romero sustentava o Realismo, o Naturalismo e o Cientificismo e a retórica do progresso em autores europeus da segunda metade do Século XIX, praticamente seus contemporâneos, como Hippolyte Taine (1818-1893), Ernest Renan e, sobretudo, Herbert Spencer. Já Machado de Assis voltava-se com frequência para Shakespeare (1564-1616), ou mesmo para os autores greco-latinos e a Bíblia e, mais ainda, voltava-se com frequência para o Século XVIII de Voltaire (1694-1778), Laurence Sterne (1713-1768), ou Xavier de Maistre (1763-1852). O Machado da segunda fase, posterior a 1880, ao recusar os pressupostos da ficção realista, nas palavras de Roberto Schwarz, recusara "os andaimes oitocentistas da normalidade burguesa". ${ }^{67} \mathrm{~A}$ própria forma que Machado assume é uma recusa em relação ao narrador confiável e onisciente. Em benefício de um narrador sinuoso, subjetivo, cheio de dúvidas e truques. João Cezar de Castro Rocha afirma que "a partir de Memórias póstumas de Brás Cubas é como se Machado de Assis escrevesse a fim de pensar a literatura". ${ }^{68}$ De certo modo, Romero percebe que a força de Machado vem justamente da linguagem, embora Machado estivesse longe de ser um mero esteta, como insinuava o crítico. Ao contrário, sua obra comporta uma poderosa, ainda que dissimulada crítica ao Brasil de seu tempo, esboçando-a em filigranas capazes de expor os interesses dominantes, as hierarquias sociais que inferiorizavam os pobres livres, mesmo a centralidade da Escravidão. ${ }^{69}$ Romero preferiu apresentar a sutileza machadiana como um meio-termo "indeciso" entre o Romantismo que entardecia, e o Realismo e o Naturalismo que despontavam: "Machado de Assis é, disse eu, um representante do espírito brasileiro, mas num momento mórbido, indeciso, anuviado, e por um modo incompleto, indireto, e como que a medo". ${ }^{70}$

O engajamento político, para Sílvio Romero, seria uma missão do intelectual, do escritor e do artista. Engajar-se nas grandes causas públicas tornar-se-ia, nas últimas décadas do Século XIX, uma forma dos escritores participarem da esfera pública por meio da palavra. O Caso Dreyfus (1894) ${ }^{71}$ e o famoso artigo de Émile Zola - intitulado "J'accuse" e publicado no jornal L'Aurore, em Paris, a 13 de janeiro de 1898 - é o exemplo máximo da intervenção do intelectual no espaço público por meio da escrita. Machado de Assis era o avesso do intelectual militante e Romero captou perfeitamente esse traço acusando-o de tibieza e "absenteísmo", pois a "virtude" dos "homens de letras" se provaria nas "lutas" em nome das grandes causas da "pátria".

[...] certo absenteísmo muito do gosto dos ânimos fracos, que entendem de salvaguardar a própria pureza, fugindo sistematicamente das tentações. É proceder que nunca aplaudiremos. A virtude prova-se no meio da luta. [...]. Devemos todos, homens de letras ou não, interessar-nos pelas pugnas e pelas dores da pátria. ${ }^{72}$

No final do Século XIX, a literatura representou um espaço privilegiado para o debate público e a militância de ideias. Apesar do modesto público leitor, em um país de maioria

${ }^{65}$ Sílvio Romero, Machado de Assis: estudo comparativo de literatura brasileira, 133.

${ }^{66}$ Ibid., 189.

${ }^{67}$ Roberto Schwarz, “A viravolta machadiana”. In: Martinha versus Lucrécia (São Paulo: Companhia das Letras, 2012 ), 248.

${ }^{68}$ João Cezar de Castro Rocha, À roda de Machado de Assis: ficção, crônica e crítica (Chapecó: Editora Argos, 2006$), 18$.

${ }_{69}$ A crítica social em Machado (já sinalizada por Antonio Candido, Vários Escritos, 1995), fez longa carreira na crítica machadiana. Sobre o assunto, para citar apenas a alguns autores entre os mais significativos exemplos, ver: Roberto Schwarz, Um mestre na periferia do capitalismo: Machado de Assis (São Paulo: Duas Cidades / Editora 34, 2012); Roberto Schwarz, Ao Vencedor as Batatas: forma literária e processo social nos inícios do romance brasileiro (São Paulo: Duas Cidades / Editora 34, 2012); John Gledson, Machado de Assis: imposturas e realismos (São Paulo: Companhia das Letras, 2005); Sidney Chalhoub, Machado de Assis, Historiador (São Paulo: Companhia das Letras, 2012).

${ }^{70}$ Sílvio Romero, Machado de Assis: estudo comparativo de literatura brasileira, 153.

${ }_{71}$ Alfred Dreyfus (1859-1935). Capitão do Exército francês, de origem judaica, envolvido em um processo caluniador de viés antissemita que o fez ser julgado e condenado (em 1894) à prisão perpétua, a ser cumprida na Ilha do Diabo, colônia penal na Guiana Francesa. Em 1906, foi provada sua inocência e reabilitado junto às armas. Morreu aos 75 anos de idade, em Paris.

${ }^{72}$ Sílvio Romero, Machado de Assis: estudo comparativo de literatura brasileira, 31. 
analfabeta, os jornais conferiam considerável espaço às discussões literárias. Nesse contexto, as polêmicas em que os autores se envolviam eram também formas de se inserir no debate público. Machado, ao contrário de Romero, não escondia em $A$ Nova Geração (1879) seu menosprezo pela postura polêmica, que muitas vezes descambava para o insulto:

[...] criticados que se desforçam de críticas literárias com impropérios dão logo ideia de uma imensa mediocridade - ou de uma fatuidade sem freio - ou de ambas as coisas; e para lances tais é que o talento, quando verdadeiro e modesto, deve reservar o silêncio do desdém: Non ragioniam di lor, ma guarda, e passa. ${ }^{73}$

Machado de Assis respondeu ao livro que Sílvio Romero lhe dedicara justamente com "o silêncio do desdém", pois, argumentava, a "tolerância é ainda uma virtude do crítico". ${ }^{74}$ Romero, ao contrário, foi um dos maiores polemistas de seu tempo, prática comum na tradição intelectual e jornalística da época, profundamente marcada pela tradição bacharelesca. Para Roberto Ventura, "a polêmica se apropriava da argumentação jurídica: cada um dos debatedores advogava a sua própria causa, como se estivesse diante de um júri hipotético, formado por um público incumbido de assistir à apresentação e a exposição das partes". ${ }^{75}$ Era a polêmica que Sílvio Romero almejava, ao contrário do Machado maduro, que as evitava, com seu "tédio à controvérsia", bem ao gosto do Conselheiro Aires. ${ }^{76}$

Diferente da proposição de Antonio Candido, Sílvio Romero compreendeu o dissenso representado por Machado de Assis e por isso mesmo o atacou, em defesa de seu próprio projeto intelectual. Ao assinalar o que seriam "os defeitos" do escritor, o crítico foi capaz de captar a incômoda novidade machadiana. Romero, entre todos os leitores contemporâneos de Machado, nota argutamente João Cezar de Castro Rocha, foi quem melhor assinalou o que hoje se considera como as principais qualidades literárias da narrativa machadiana:

Por tudo dizer sem rodeios, Sílvio Romero talvez tenha sido o leitor contemporâneo mais agudo de Machado de Assis, porque foi o único que destacou, com ênfase, as qualidades que hoje reconhecemos como tipicamente machadianas. Somente Romero viu nessas características defeitos que comprometeriam o talento que nunca negou ao escritor fluminense [...]: a fragmentação narrativa; a recusa do grandiloquente; a visão de mundo cética; a desconstrução de sistemas filosóficos; a irônica compreensão da formação social brasileira; a tartamudez, ou seja, a escrita de um narrador ébrio, que atravessa o texto ziguezagueando, deixando os leitores do usual romance oitocentista literalmente tontos. ${ }^{77}$

Sílvio Romero sentiu-se compelido a atacar a obra de Machado por que percebeu a radical recusa contida, ainda que ela aparecesse destituída da retórica do confronto. O crítico afirmou que o escritor "não é da raça dos humanitários propagandistas e evangelizadores de povos ao gosto de Tolstói. É, a meu ver, uma espécie de moralista complacente e doce, eivado de certa dose de contida ironia". ${ }^{78}$ A rigor, "propagandista e evangelizadora", era, sim, a própria obra romeriana. O “esquema de Machado" era outro. Através de personagens como Bento Santiago e Brás Cubas, ambos proprietários, inclusive de escravos, o escritor explorou um olhar intimista, marcado pelo pessimismo e pela nostalgia de um mundo que declinava, o da Escravidão, de onde provinha o sentimento de traição dos agregados, que já não mais atendiam a vontade senhorial, como sugere

\footnotetext{
${ }^{73}$ Machado de Assis, “A nova geração”. In: Obra Completa de Machado de Assis, vol. III (Rio de Janeiro: Nova Aguilar, 1994), 829.

${ }^{74}$ Machado de Assis, Obra Completa de Machado de Assis, 800.

${ }^{75}$ Roberto Ventura, O estilo tropical: história intelectual e polêmica literária no Brasil (São Paulo: Companhia das Letras, 1991), 149.

${ }^{76}$ Personagem central do último romance de Machado de Assis, Memorial de Aires, de 1908.

${ }^{77}$ João Cezar de Castro Rocha. “'O ruído das festas' e a fecundidade dos erros: como e por que reler Sílvio Romero”, Revista Tempo Brasileiro: Repensando o Brasil com Sílvio Romero [n.] 145 (2001) (84-85).

${ }^{78}$ Sílvio Romero, Machado de Assis: estudo comparativo de literatura brasileira, 318/19.
} 
Sidney Chalhoub. ${ }^{79}$ Ou seja, o modo machadiano de se engajar na vida de seu "país e do tempo" era por meio da literatura, de fato bem diferente da "raça dos humanitários propagandistas e evangelizadores de povos", tão ao gosto dos escritores e intelectuais realistas e naturalistas. Para Romero, "Machado de Assis é bom quando faz narrativa sóbria, elegante, lírica dos fatos que inventou ou copiou da realidade; é quase mal quando se mete a filósofo pessimista e a sujeito caprichosamente engraçado". ${ }^{80}$ Para o autor da História da literatura brasileira, a experiência brasileira não pedia ironia, mas crítica; o atraso do país não justificava um pessimismo elegante, mas um otimismo mobilizador das forças; o atraso e a pobreza não autorizariam o bumour, mas o espanto. A obra literária de Machado de Assis não apenas divergia de seu projeto político e intelectual, como lhe criticava severa e silenciosamente o âmago de intelectual mobilizado pela retórica da ciência e do progresso, da nacionalidade e das "dores da pátria".

Machado de Assis, como se sabe, não cedeu ao cientificismo determinista e racista de seu tempo, antes o ironizou, como já foi apontado. A sua recusa foi de grandes proporções, pois o livrou de condenar os negros, os mestiços e a desconfiar do futuro do país, como intelectuais modernizantes o fizeram, entre eles, Sílvio Romero. Mas, por que Machado foi capaz de operar essa recusa? Para o escritor mexicano Carlos Fuentes, a resposta está na biblioteca de Machado de Assis, que não se deixou aprisionar nem colonizar pelas percepções hegemônicas na Europa da segunda metade do Século XIX, marcadas pelo Realismo e Naturalismo e, junto deles, o cientificismo e o determinismo, buscando referências em outros autores e noutros tempos. A tradição crítica em torno da obra de Machado de Assis já apontou a pontes entre o escritor e as obras, como já dissemos, de Shakespeare, Voltaire, Diderot (1713-1784), Laurence Sterne, Xavier de Maistre, entre outros, mas Carlos Fuentes (1928-2012) salienta a relação entre Machado e a tradição literária herdada de Miguel de Cervantes (1547-1616), de onde teriam vindo novos elementos para operar uma recusa criadora e, por isso mesmo, crítica:

[...] el milagro se sostiene sobre una paradoja: Machado asume, en Brasil, la lección de Cervantes, la tradición de La Mancha que olvidaran, por más homenajes que cívica y escolarmente se rindiesen al Quijote, los novelistas hispanoamericanos de México. ${ }^{81}$

Sílvio Romero, como a maioria dos intelectuais latino-americanos do Século XIX sentiramse impedidos de buscar nas tradições ibéricas e ibero-americanas as fontes capazes de alimentar suas inquietações, optando por desbragada obsessão pelo progresso, com tudo o que isso significava. Diz Fuentes: "Habia que ser yanque, francés, o britanico para ser moderno y para ser, aún más, próspero y civilizado", 82

Para Romero, os fundamentos essenciais da nacionalidade residiriam na formação de uma tradição popular, associada a histórica presença lusitana, indígena e africana, que remontava ao passado colonial, gerador da mestiçagem brasileira. E "todo brasileiro é mestiço, quando não no sangue, nas ideias". ${ }^{33}$ Mas na herança colonial também estaria a origem do atraso brasileiro, pelas mesmas razões: o legado luso-mestiço e escravocrata teria deixado para o futuro a falta de uma "mentalidade industriosa". O próprio colonizador ibérico foi apresentado de um modo sinuoso, ora louvado, ora detratado, daí a necessidade de uma nova direção para o Brasil, que superasse sua herança colonial. O elogio às "grandes nações criadoras" significou a defesa do mundo moderno, ao qual Sílvio Romero relacionava às "nações anglo-germânicas", países que teriam aberto a "era moderna" e nelas poderiam ser encontradas as "lições" a fim de "corrigir as debilidades latinas".

\footnotetext{
${ }^{79}$ Sidney Chalhoub explora as relações entre Machado de Assis e o declínio da Escravidão. Fundamentado na História Social, o historiador talvez exagera no olhar documental, ainda que seu livro seja proveitoso. Cf. Sidney Chalhoub, Machado de Assis, Historiador (São Paulo: Companhia das Letras, 2012).

${ }^{80}$ Sílvio Romero, Machado de Assis: estudo comparativo de literatura brasileira, 320.

${ }^{81}$ Carlos Fuentes, Machado de la Mancha (Ciudad del México: Fondo de Cultura Económica, 2002), 10.

${ }^{82}$ Ibid., 9.

${ }^{83}$ Sílvio Romero, História da literatura brasileira, 55.
} 
O povo brasileiro não pertence ao número das nações inventivas; tem sido, como o português, organicamente incapaz de produzir por si.

Tanto quanto se deve aos povos fracos aconselhar que busquem exemplo nas grandes nações criadoras [...]. Tocando em fatos diretos, basta não esquecer que às gentes do Norte, tendo hoje a sua frente os ingleses e alemães, está reservado o papel histórico, já vinte vezes cumprido, de tonificar de sangue e ideias os povos latinos, célticos e ibéricos do Meio-Dia. ${ }^{84}$

Para reorientar a cultura brasileira no sentido da Europa do Norte era preciso, pensava Romero, assumir uma postura militante, ensinando os brasileiros a serem outros. Postura narrativa muito distante de Machado, cujo texto dialoga com o leitor, ironiza, mas não "ensina", nem assume uma voz de autoridade, à maneira de Sílvio Romero. A perspectiva machadiana, muito diferente da postura de um narrador onipotente, pronto para "ensinar", como em Sílvio Romero, que se dirigia ao leitor em tom professoral, discorrendo com a autoridade da ciência, portador de saberes autorizados e contemporâneos, rumo ao futuro. Não se trata apenas de uma diferença de estilos, abordagens ou capacidades, mas de diferentes funções atribuídas ao texto. Romero escrevia imbuído de uma missão: incitar a ação. Machado, ao contrário, foi muito menos suscetível aos discursos hegemônicos, menos interessado nas grandes teorias explicativas, antes disposto a flagrar a universalidade do homem nas suas estratégias veladas, no cálculo escondido atrás da generosidade ou da ingenuidade, no jogo das aparências e no interesse de classes dissimulado.

Sabemos que todo escritor ou crítico, ou historiador é, antes de tudo, um leitor. Entre a leitura e a escritura há vasos comunicantes decisivos, pois quem escreve o faz a partir de suas leituras, de seus fantasmas, de seu horizonte político e de sua historicidade. Logo, todo texto é animado por releituras do repertório cultural e político que assume (por múltiplas e variadas razões). As diferenças e desavenças entre Romero e Machado passaram, em boa medida, por suas leituras e bibliotecas.

Como a fortuna crítica em torno de Machado amplamente demonstrou, o Bruxo de Cosme Velho rejeitou o essencialismo biologizante nascido da ciência do século XIX, diferente das reflexões de muitos intelectuais da geração de 1870. Os argumentos de Machado foram de natureza histórica e cultural, distantes das categorias biológicas e raciais, tão presentes na obra Silvio Romero, um intelectual comprometido com a retórica do progresso e da nacionalidade, assentava sua condição de leitor nos autores do Século XIX, em torno do evolucionismo de Spencer, do monismo de Haeckel, da crítica de Hippolyte Taine e Ernest Renan, autores que acionaram nele um avassalador dispositivo determinista, caracterizado pela adoção dos princípios constitutivos das Ciências naturais e do saber empírico e objetivista, inclusive o racialismo. Outro horizonte da leitura romeriana foi a apropriação dos autores alemães e, por meio deles, a adesão ao nacionalismo estético e político. Lembremos que grande parte da cultura intelectual alemã, certamente diversa, foi marcada pela busca e afirmação do nacional. Sobre isso, são esclarecedoras as palavras do próprio Romero:

E hoje é preciso ser muito refratário a certa forma superior da cultura para não ter lido Kant, Hegel, Schopenhauer, Hartmann, Nietzsche, Lange, Zeller, Bluntschli, Holltzendorf, Savigny, Ihering Mommsen, Curtius, Sybel, Droysen, Gneist e Max Müller, Strausss, Haeckel, Vogt e cinqüenta outros. ${ }^{85}$

Em outro momento, Romero reforça a sua herança alemã:

\footnotetext{
${ }^{84}$ Sílvio Romero, História da literatura brasileira, 167.

${ }^{85}$ Ibid., 337.
} 
O século XVIII no seu final é altamente importante por dois fatos capitais que o dominam: a agitação política que se afirma na Revolução Francesa e a agitação literária e científica que se resolve no romantismo alemão, precursor do romantismo inglês e francês, e na crítica de Lessing, de Wolf, de Herder, de Kant, de Winckelmann, os grandes guias do pensamento germânico. ${ }^{86}$

Não apenas por essas passagens, mas pelo conjunto de sua obra, o engajamento de Sílvio Romero como crítico e intelectual foi muito diferente do de Machado de Assis como escritor, pois praticou uma leitura e uma obra a partir dos horizontes letrados hegemônicos na Europa Ocidental do Século XIX - Alemanha, França e Inglaterra, à frente. Machado de Assis, por sua vez, não aderiu nem ao cientificismo em termos teóricos, nem ao naturalismo em termos literários, e nem mesmo ao nacionalismo em termos políticos. Justamente por isso Machado não se viu na obrigação de condenar o Brasil pelas "raças" que o compunham, nem questionar suas mestiçagens. Por não aderir à retórica do progresso, o escritor não se viu na obrigação de combater o "atraso" brasileiro.

O Machado da segunda fase, de Memórias póstumas de Brás Cubas (1880) em diante, não se limitou ao diálogo com os grandes autores de seu tempo - de Victor Hugo (1802-1885) a Flaubert (1821-1880), de Zola a Eça de Queiroz - enfim, da grande tradição romântico-realista do Século XIX, nem se deixou pautar pelos teóricos cientificistas, como Herbert Spencer ou Hippolite Taine, mas também praticou uma contínua leitura com outros tempos, outras temporalidades, outras tradições e, mesmo, com outra Europa. Enquanto Romero encarnou o Século XIX, o século das nações e do progresso, Machado de Assis foi ávido leitor da tradição clássica de Dante (12651321), de Gil Vicente (1465-1537), de Fernão Mendes Pinto (1509-1583), de Camões (ca. 15241579/80) e de António Vieira (1608-1697), de Pascal (1623-1662), Shakespeare, Molière (16221673) e Racine (1639-1699), e os já mencionados autores do Século XVIII: Voltaire, Laurence Sterne, ou Xavier de Maistre. Dialogou ainda com a Bíblia e os autores latinos. ${ }^{87}$ Esse diálogo fez que Machado evitasse o tom doutrinário e "evangelizador" da ciência moderna, do Naturalismo e do Realismo, cultivando o humor e a dúvida e, sobretudo, valorizando a relação, assumindo um tom fragmentário e subjetivo.

Para Alfredo Bosi, Machado foi um profundo leitor dos jansenistas franceses, o que teria feito dele um herdeiro da vertente cética do Iluminismo. ${ }^{88}$ A precisão da leitura de Bosi não é fundamental para esse trabalho, mas sim a tese segundo a qual Machado, ao contrário de Romero, dialogou com tradições letradas próprias de outros tempos, o que permitiu que o escritor fluminense relativizasse, ou mesmo se opusesse, a retórica do progresso (com seus cientificismos biologizantes). No entanto, o diálogo com antigas tradições letradas não retiram de Machado a condição de atento observador de seu país e de seu tempo, como querem John Gledson, Roberto Schwartz e Sidney Chalhoub. Sua capacidade de criticar tanto a ordem liberal conservadora, monárquica e escravocrata que entardecia, quanto o cientificismo republicano que amanhecia, mostra a força de sua dissidência.

\footnotetext{
86 Ibid., 460

${ }^{87}$ João Cezar de Castro Rocha, em Machado de Assis: por uma poética da Emulação (Rio de Janeiro: Civilização Brasileira, 2013), desenvolve uma longa e erudita explicação para o salto qualitativo do Machado de Assis da segunda fase. O escritor teria recuperado a prática retórica da aemulatio, própria da cultura letrada do Antigo Regime, cujo princípio central está na “emulação" dos grandes autores da tradição clássica. Machado, deliberadamente anacrônico, por isso criativo e pósromântico, teria recuperado elementos da prática literária pré-romântica. O romantismo, com sua defesa da originalidade e da singularidade, prescindiu do domínio da cultura clássica. Machado teria sido capaz de produzir uma prática literária nova justamente por que soube retomar velhos diálogos, produzindo uma literatura para além dos cânones oitocentistas. Não é objeto deste artigo avaliar a instigante e bem documentada tese do autor em questão, mas insistir na postura de Machado leitor dos antigos, como Castro Rocha demonstra. O que permitiu a Machado superar os limites oitocentistas, vale dizer, e contornar as limitações impostas pela retórica do progresso e do nacionalismo.

${ }^{88}$ Alfredo Bosi, "Machado de Assis". In: Coleção Folha Explica (São Paulo: Folha Publicações, 2003).
} 
Enquanto Romero defendia o "homem de ciência" e o militante político engajado nas lutas e "dores da pátria", 89 - Machado, de modo aparentemente conservador, propunha a independência da literatura frente a objetivos políticos, a maneira de um letrado "absenteísta", segundo a retórica romeriana. O engajamento do "liberal spenceriano" Silvio Romero o levou a condenação racista de grande parte da população brasileira, de um modo determinista e autoritário. ${ }^{90}$ Já o Machado da segunda fase, pós-romântico e pós-realista, praticante de uma literatura subjetivista e fragmentária, permeada pelo diálogo transtemporal com os antigos, possibilitou que criticasse a ordem social, sem jamais aderir incondicionalmente aos pressupostos oitocentistas do progresso e da modernidade. Machado soube recusar o racismo e o eurocentrismo, de um modo que o nacionalista e cientificista Sílvio Romero (e da maioria dos homens de sua geração) não foi capaz de fazer.

${ }^{89}$ Sílvio Romero, Machado de Assis: estudo comparativo de literatura brasileira, 31.

${ }_{90}$ Richard Miskolci, "Machado de Assis, o outsider estabelecido". Sociologias, Porto Alegre, ano 8, [nº] 15, jan/jun (2006): (373), 352-377. 